IZA DP No. 5068

How Economics Helped Shape American Judaism

Carmel Ullman Chiswick

July 2010 


\title{
How Economics Helped Shape American Judaism
}

\author{
Carmel Ullman Chiswick \\ University of Illinois at Chicago \\ and IZA
}

Discussion Paper No. 5068

July 2010

IZA

P.O. Box 7240

53072 Bonn

Germany

Phone: +49-228-3894-0

Fax: +49-228-3894-180

E-mail: iza@iza.org

Any opinions expressed here are those of the author(s) and not those of IZA. Research published in this series may include views on policy, but the institute itself takes no institutional policy positions.

The Institute for the Study of Labor (IZA) in Bonn is a local and virtual international research center and a place of communication between science, politics and business. IZA is an independent nonprofit organization supported by Deutsche Post Foundation. The center is associated with the University of Bonn and offers a stimulating research environment through its international network, workshops and conferences, data service, project support, research visits and doctoral program. IZA engages in (i) original and internationally competitive research in all fields of labor economics, (ii) development of policy concepts, and (iii) dissemination of research results and concepts to the interested public.

IZA Discussion Papers often represent preliminary work and are circulated to encourage discussion. Citation of such a paper should account for its provisional character. A revised version may be available directly from the author. 
IZA Discussion Paper No. 5068

July 2010

\section{ABSTRACT}

\section{How Economics Helped Shape American Judaism*}

This chapter discusses the strong impact of economic forces, and changes in the economic environment, on American Jewish observance and American Jewish religious institutions in the $20^{\text {th }}$ century. Beginning with the immigrants' experience of dramatic economic change between the old country and the new, it focuses on how this affected differences between European and American Jewish practices during the first half of the twentieth century. Equally dramatic upward economic mobility had implications for additional changes during the second half of the century. These were manifested by the development of distinctively American patterns of Jewish education. The relationship between Jewish education in the United States and the other major branches of World Jewry is discussed from an economic perspective. The economic underpinnings of religious intermarriage and assimilation are reviewed. A concluding section forecasts the future of American Judaism and Jewish observance in the coming decades.

JEL Classification: Z12, N32, J12

Keywords: economics, religion, Judaism, economic history, immigrant adjustment, education, intermarriage

Corresponding author:

Carmel U. Chiswick

Department of Economics

University of Illinois at Chicago

601 S. Morgan Street

Chicago, IL 60607-7107

USA

E-mail: cchis@uic.edu

\footnotetext{
* Prepared for The Oxford Handbook of Judaism and Economics (Aaron Levine, ed.)
} 


\title{
HOW ECONOMICS HELPED SHAPE AMERICAN JUDAISM
}

\author{
By \\ Carmel Ullman Chiswick \\ University of Illinois at Chicago
}

The United States presents an economic environment unlike any other in the millennia-long experience of the Jewish people. As the "Great Experiment” in democracy and religious freedom, America broke with its European roots in ways that greatly reduced the economic penalties imposed by society on Jews per se. American Jews were subject to no special taxes and faced no laws restricting their ability to choose an occupation, to own property, or to enforce contracts. Although anti-Semitism was not completely absent, other minority religious and ethnic/racial groups also faced challenges in America. For European Jews, America was truly a land of opportunity.

In addition to its promise of freedom, the United States participated with the rest of the Western world in a series of technological advances with such dramatic economic and social impacts that they were referred to as an industrial "revolution.” New inventions made workers far more productive than they had ever been in the past, mass production greatly reduced the cost of manufactured goods, new modes of transportation supplied city dwellers with inexpensive food, and new technologies in communication connected people in ways that would have been unfathomable in a previous era. The real wages of ordinary workers, conventionally measured as the purchasing power earned by working for one day or one hour, rose to unprecedented levels.

The new technology also placed a high premium on skills, both on the factory floor (blue-collar workers) and in the front office (white-collar workers). The United States was the first country to develop a large-scale system of colleges and universities 


\section{Chiswick - Shaping American Judaism}

that were readily accessible to many families. The highly-educated graduates of this system would command a substantial wage premium throughout the $20^{\text {th }}$ century as they facilitated the innovation and adoption of new technologies. Jews, with their traditional emphases on education and on adaptability to new opportunities, participated eagerly and successfully in this process. In a country where real wages were rising for all workers, Jews were acquiring higher education and thus moving toward the higher end of the rising American wage distribution.

This was the economic context in which American Judaism developed its own set of religious practices. Judaism's Great Tradition - Tanach, Talmud, and Rabbinic rulings - would not change, for this is the core that defines Judaism as a religion and Jews as a people. Its European Ashkenazi traditions, however, were not immutable. Religious practices that involved purchasing goods might have been too expensive for Jews in a Russian shtetl, but would be well within the means of even poor Jews in America. In contrast, any practice that required long hours in the synagogue would be far more costly for a high-wage American Jew with many attractive alternatives for leisure as well as work activities. These differences in the relative prices of goods and of time would be instrumental in altering religious practices and hence the shape of Judaism in the United States.

Jewish adaptations in America included the $19^{\text {th }}$-century split into three main synagogue movements (Reform, Conservative, and Orthodox) and the development of a wide variety of communal organizations for social and political as well as charitable purposes. During the $20^{\text {th }}$ century these synagogue movements and their various offshoots would come to characterize a distinctively American Jewish religious identity. 


\section{Chiswick - Shaping American Judaism}

Also during the $20^{\text {th }}$ century the emergence of Israel as a major cultural, political and economic center - and a focal point of Jewish life - would have important effects on the cost of being Jewish, and hence religious practices, in the Diaspora.

This paper explores the economic forces that facilitated and supported these and other changes in American Judaism. It deals first with the immigrant experience and changes in economic incentives associated with upward educational and occupational mobility. It then looks specifically at how this context affected the economics of Jewish religious education in the $20^{\text {th }}$ century. Within the framework of World Jewry, the relationship between the United States, Europe and Israel is discussed with regard to the comparative advantage of each community in Jewish education. The economic underpinnings of assimilation in the later decades of the $20^{\text {th }}$ century is discussed next, viewed mainly as an unintended consequence of economic decisions made by Jewish immigrants and their children during their adjustment an economic environment in America with virtually no precedent in Jewish experience. In conclusion, these various economic analyses are used to provide a forecast for the future of American Judaism.

\section{THE ECONOMICS OF IMMIGRANT ADJUSTMENT}

Jews, like nearly everyone else in the United States, originally came to America as immigrants. The earliest Jewish immigrants had to form their own communities, but later immigrants could choose between joining an established Jewish community and forming a new one. In either case, however, an immigrant's primary concern would be to earn a living and adjust to economic circumstances in the new country. The greater the difference between economic life in the old country and the new, the more difficult 


\section{Chiswick - Shaping American Judaism}

this adjustment would be and the more likely that economic concerns would heavily influence other aspects of an immigrant's new life.

The earliest American Jewish communities were Sephardic, with members whose occupations in international trade and finance placed them in comfortable economic

circumstances. ${ }^{1}$ In the mid- $19^{\text {th }}$ century, however, they were greatly outnumbered by a wave of Ashkenazi immigrants from German-speaking areas of Central Europe. Many of the German Jewish immigrants were poor, beginning their American experience as itinerant peddlers and eventually working their way up the socio-economic ladder by expanding their retail operations. The German Jews brought with them Ashkenazi traditions, often modified by changes introduced by the early Reform movement in Germany. In the last decades of the $19^{\text {th }}$ century their communities were in turn outnumbered by the massive influx of Yiddish-speaking Jews from Russia and Eastern Europe, ancestors of some 95 percent of today’s American Jews. The immigrant Russian Jews arrived with few assets and worked mostly as ordinary laborers, operatives and craftsmen, but as they and their offspring improved their economic circumstances they moved into a variety of occupations, including especially the professions associated with higher education.

\section{THE IMMIGRANT EXPERIENCE}

American Jewish history is thus dominated by the story of Jewish immigrants making the transition from the old world to the new, always seeking opportunities to improve their economic condition. In this respect they followed the well-established model of immigrant economic adjustment. ${ }^{2}$ Many of the skills they found useful in the old country did not transfer well to the new, their English was poor and they lacked skills 


\section{Chiswick - Shaping American Judaism}

with high market value. As a result, they would accept low-paying jobs to support themselves while learning such country-specific skills. Perhaps the most important of these skills was the English language, but also important were American customs associated with the job market, such as how to look for and land a good job, how to behave toward supervisors and colleagues, and how to develop efficient networks for finding a job or establishing a business. Also important was knowledge useful in their role as consumers, such as learning the relative prices of goods and services, finding stores with low prices, or where and when to find the good bargains. Although real wages were much higher in the United States than they had been in their countries of origin, new immigrants could not always command the higher wages until they had made these investments in US-specific skills.

Like many other immigrant groups, Jewish immigrants established synagogue communities in the new country with a minimum of changes. Storefront synagogues, or shteibls, were common in the poor Jewish neighborhoods, serving in effect as inexpensive replicas of familiar old-country synagogues. They were places where people with a shared experience and history could meet, where a person could hear and speak a familiar language and fit into a familiar social structure, and could thus serve as an emotional haven in a strange, confusing world. They also served as information exchanges, as a place to learn the ways of the new country and to network for a better job or for new customers. In this they were the Jewish counterpart of the "immigrant church" that plays an important role in immigrant adjustment during the early years in a new country. ${ }^{3}$ 


\section{Chiswick - Shaping American Judaism}

Although the storefront synagogues replicated as much as possible the oldcountry religious traditions of Russian Jews, there was one very important difference. The opportunity cost of time was very much higher in the United States than it had been in Europe, making every hour of synagogue attendance and home religious observance that much more costly. Even newcomers in low-paying jobs were investing in workrelated skills that would raise their future earnings, thus raising the opportunity cost of time well above their actual wage rate. People responded to the high value of time by reducing their synagogue attendance and religious ritual activities. For many, the Sabbath and most holiday observances were increasingly confined to the home where they could be comfortably abbreviated, the main exception being the High Holy Days of Rosh Hashanah and Yom Kippur. ${ }^{4}$

The education of Jewish children in the immigrant neighborhoods was also affected by the high opportunity cost of their time. Jewish immigrants understood that an important route to upward socio-economic mobility in the United States was through a good secular education, and they were willing to work hard and sacrifice their own consumption levels in order to keep their children in school. The opportunity cost of the child's time, measured as the expected payoff to this educational investment, would have been quite high. In contrast, the expected payoff to an investment in Jewish education was much lower, in part because it would have had little effect on labor market earnings and in part because the immigrants overestimated the extent to which children could learn Judaism by simply living among other Jews. The Jewish religious professions - rabbi, cantor, Hebrew teacher, shochet, mohel - were low-paying occupations and therefore without much prestige in the immigrant community. An international trading system 


\section{Chiswick - Shaping American Judaism}

was developed for these skills: an American Jewish community could send for someone trained in Europe who would work cheaply and consider himself well-paid, although after a few years he might move on to a more lucrative occupation and be replaced by another newcomer.

\section{AMERICANIZATION AND UPWARD MOBILITY}

Once an immigrant has had a few years to adjust and to learn about the new economic environment, he or she typically chooses a niche in which to build a career and family. ${ }^{5}$ Sometimes this involves moving up the job ladder within a firm or industry, sometimes it involves establishing and building a business enterprise, and sometimes it involves acquiring the education needed to enter a profession. This is a period when earlier investments in US-specific skills are beginning to pay off as the immigrants become more “Americanized.” At the same time immigrants in this phase of their economic adjustment invest heavily in their chosen path, acquiring a reputation for hard work and long hours. As they move out of poverty and into the middle class, the opportunity cost of their time is even higher than before.

For immigrants at this stage of assimilation into the American economy, timeintensive religious traditions were increasingly expensive. The newly-emergent American lifestyles were becoming less and less complementary with the old-country Jewish observances that had been comfortable for people in very different circumstances. As the German Jews established themselves during the second half of the $19^{\text {th }}$ century, they founded new Ashkenazi synagogues with “reformed” practices more compatible with their new economic environment. ${ }^{6}$ These reforms were influenced by the classical 


\section{Chiswick - Shaping American Judaism}

Reform movement in Germany, which had arisen along with the rapid economic development of that country, but their ready acceptance by American Jews was encouraged by the fact that they reduced the time-intensity of Jewish religious observance.

Many American Jews stopped observing kashrut, especially those living outside of the big-city Jewish enclave neighborhoods. This was only partly because the scarcity of kosher butchers would have made the price of meat very expensive. More importantly, American Jews were participating actively in an open and collegial society in which shared meals played an important social role. The opportunity cost of not joining their non-Jewish neighbors for business lunches or social dining would have been quite high, thus providing a strong economic incentive to accept Reform Judaism’s rejection of kashrut as an “obsolete” observance.

Reform synagogues adopted other “American” practices, greatly abbreviating the religious service, conducting prayers in English as well as in Hebrew, and introducing mixed seating with men and women together. As these reforms gained momentum, imported clergy trained in European seminaries were less and less prepared to serve in American congregations. As the German Jews continued to prosper in America, they established the Hebrew Union College to train rabbis to serve in Reform synagogues. In the spirit of this new movement, the first graduation ceremony in 1883 was celebrated with the infamous “Trefa Banquet”, followed shortly thereafter by the formal establishment of Reform Judaism with its even more radical "Pittsburgh Platform”. 7

By the time the Russian Jews moved into middle-class neighborhoods, the American Reform Movement was already established. For many, joining a Reform 


\section{Chiswick - Shaping American Judaism}

synagogue was simply another step in their Americanization process. Others, however, were not comfortable with the radical ideology of that movement. They had no difficulty abandoning the storefront synagogues, which they had long ago ceased to attend with any enthusiasm, but their new Conservative synagogues retained the use of Hebrew ritual even as they introduced English for translations and for a sermon. The Conservative Movement did not abandon kashrut, nor did it drop the observance of Shabbat, although many of its individual members honored these religious laws in the breach.

Orthodox synagogues retained many more of the old-country Ashkenazi religious traditions, but in many respects they were the Jewish counterpart of "immigrant churches." ${ }^{8}$ As immigrants became more fluent in English and found an economic niche for themselves, their time became more costly and their need for a "safe haven" less urgent. As an alternative to joining an "American” congregation, however, the immigrant religious community might simply move its old synagogue to the new neighborhood. In such cases, the synagogue service inevitably changed along with changes in the congregants' circumstances. Upward economic mobility made timeintensive practices more costly and donations more feasible, leading to a systematic tendency toward substituting money for time. Congregants were willing to maintain a building and hire clergy, but their own attendance at services tended to decline. Language study is time-intensive, so English was relied on to make the services "relevant” for congregants with limited Hebrew skills. As religious practices responded to the new incentives, and as the members became more "American" in their lifestyles and sensibilities, synagogue activities were increasingly laced with a heavy dose of nostalgia for traditions that were inevitably disappearing from American Jewish life. 


\section{Chiswick - Shaping American Judaism}

Immigrant churches in general rarely survive more than a generation or two. The immigrants themselves, and some of their children, may continue their attachment to the old-country traditions, but their grandchildren have no direct ties to the old country and are often impatient of the nostalgia enjoyed by their elders. In an upwardly mobile community, the opportunity cost of time is substantially higher for the third generation than for the first- and perhaps even the second-generation immigrants. Some young people left for less time-intensive Conservative or Reform “American” congregations when they moved out of the immigrant neighborhoods, while others remained Orthodox only as long as their parents or grandparents survived. Throughout the first half of the $20^{\text {th }}$ century, the rising opportunity cost of time in the American Jewish population goes far toward explaining the oft-noted intergenerational progression of many American Jewish families from Orthodox to Conservative to Reform and the declining membership in Orthodox synagogues.

Outside of the synagogues, the upwardly mobile community developed a variety of institutions to address the philanthropic, political and social needs of American Jewry. Although elsewhere these functions might be the province of the religious communities, this was not the case in the United States where pluralism generated a different structure

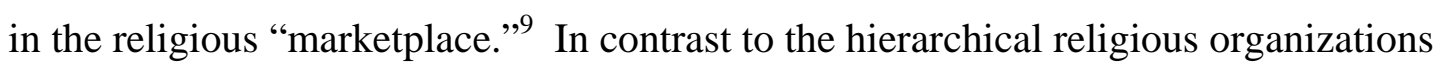
typical in countries with a state religion, American churches and synagogues were characterized by congregationalism, that is, an organizational structure in which congregations are founded and administered by their lay membership. Without any central authority, these congregations typically form umbrella organizations organizations in which churches or synagogues per se are members - to serve common 


\section{Chiswick - Shaping American Judaism}

religious interests. The Union of American Hebrew Congregations, the United Synagogues of America, and the Orthodox Union were formed in the late $19^{\text {th }}$ century and continue to dominate American Jewish religious life to this day. A congregationalist market structure also leads to the formation of para-religious organizations to serve the non-religious social and political needs of the religious community. For American Jewry these included not only charities for support to the needy but also organizations that helped the socio-economic assimilation of Jewish immigrants (e.g., the Hebrew Immigrant Aid Society, the Anti-Defamation League), and those that reinforced ties to World Jewry (e.g., Jewish National Fund, the Joint Distribution Committee, Hadassah and other Zionist organizations).

As noted above, during this demanding phase of their economic adjustment Jewish immigrants worked long and hard as they invested heavily in their business or profession. The opportunity cost of their time was high, and virtually all of their consumption patterns changed in response. Wherever possible, Jewish immigrants and their children sought to reduce the time-intensity of consumption, and Jewish religious observance was no exception. For some this meant simply reducing their religious observance, but for most it meant religious innovations that would permit substituting money for time. Even as rising wages made time more costly, rising incomes made financial support less difficult. Even as American Jews spent less and less time in the synagogue and in home-based religious observance, they joined and supported new synagogues and gave generously to para-religious charities and communal organizations. Although American Jews were often derided as “non-observant” and “materialistic,” they 


\section{Chiswick - Shaping American Judaism}

were also following a long-standing Jewish tradition by adapting their religious practices to a new economic environment.

\section{THE ECONOMICS OF JEWISH EDUCATION}

Education - broadly defined - is the process of investing in human capital. Whether formal or informal, education provides skills useful for consumption as well as production. It is also the means of transmitting the stock of human knowledge from one generation to the next. Jews have always emphasized the importance of education, both secular and religious. A full understanding of how economic incentives affected the shape of American Judaism requires an understanding of how they affected Jewish education.

At the turn of the $20^{\text {th }}$ century the Yiddish-speaking immigrants from Russia and Eastern Europe were far more preoccupied with acquiring secular skills than they were with Jewish education. The financial payoff to secular skills was very high, and there were many new and exciting cultural, political, and social activities to learn about. In contrast, the early religious institutions that they established were familiar (if not actually perceived as boring) and depended mainly on a set of old-country skills that could be transferred successfully to the new environment. The large difference in rates of return between investments in secular and Jewish human capital led invariably to a strong focus on the former and a marked separation between secular and religious education that would persist for many decades.

Investment in secular human capital was a very high priority for Jewish immigrants. For adult men this usually meant learning English and acquiring job-related 


\section{Chiswick - Shaping American Judaism}

or business skills. Jewish women were eager students in settlement houses and learned to use new cookbooks and other "how-to" manuals, many of which were published in Yiddish. ${ }^{10}$ Immigrant parents sent their children to the public schools and were willing to make great sacrifices, if necessary, to keep them there as long as possible. Most of these children continued through high school, and many - especially the boys - would continue their education in college. According to a survey of Jewish men taken in the year 2000, more than 25 percent of those born before 1940, most of whom would have been the sons of immigrant parents, had not only graduated from college but had also earned some post-graduate professional degree. ${ }^{11}$ This is more than double the corresponding figure for non-Jews and is testimony to the very high priority American Jews placed on secular education.

Increases in the level of secular education had far-reaching implications for the economic environment of American Jewry. Schooling provided the skills that qualified men for higher-paying occupations, raising both incomes and the opportunity cost of time. By the early post-WWII years nearly 60 percent of all Jewish men were working in high-level occupations, as compared to less than 25 percent of the non-Jews. Of these, about one-fourth (14 percent) were professionals whose occupations would have required an advanced degree. Another two-thirds (45 percent) were in managerial occupations, a category that includes owners who manage their own companies but not the owners of small “mom-and-pop” establishments. The proportion in professional occupations would increase steadily for the rest of the century to more than half of the total, and the proportion in management would eventually decline to less than 20 percent, but together these high-level occupations would continue to account for about two-thirds of the 


\section{Chiswick - Shaping American Judaism}

American Jewish male labor force. By way of comparison, in the year 2000 less than 20 percent of non-Jewish American men were in the professions and high-level occupations accounted for only about 35 percent of the total. ${ }^{12}$

People in these high-level occupations have skills that place them at the upper end of the U.S. earnings distribution. Many of these occupations were male-dominated until the later decades of the $20^{\text {th }}$ century, at which point Jewish women entered them in disproportionately large numbers. Jewish women were much more likely than their nonJewish counterparts to have attended college, and for every cohort born after World War II more than 25 percent of the Jewish women (compared to about 10 percent of nonJewish women) went on to earn an advanced post-college degree. ${ }^{13}$

With the focus on acquiring secular skills that conferred upward economic mobility, Jewish education received much less attention. Families had limited money budgets and students had limited time budgets. The rate of return to secular education was large and obvious, while the economic return to a Jewish education was much less so. For many immigrants Judaism was so fundamental to their self-concept that they simply could not imagine that it might be otherwise for their children. Yet with little attention given to religious studies and not much time spent in home observances, most of the Jewish human capital acquired by second-generation immigrants was what they

learned by living in an ethnically Jewish community. ${ }^{14}$ Religious human capital acquired in this way was at best perfunctory; although Jewish ethnic characteristics might survive a subsequent move to the non-Jewish suburbs, religious knowledge was often too weak to be imparted to the next generation. The grandchildren of immigrants would grow up to embody the classic American Jewish imbalance, with very high secular skills and very 


\section{Chiswick - Shaping American Judaism}

low religious skills. The marginal product of time spent in secular activities would thus be very much higher than in Jewish religious observance, and this in turn would induce a further shift in the time budget from religious to secular activities. ${ }^{15}$

Even as the two types of education compete with each other for resources, the human capital which they create can be mutually complementary. For example, Jews with a strong background in religious studies, especially advanced Talmud study, often excel in secular studies as well. While cause and effect have yet to be well understood, this is a plausible explanation for the fact that Jews faced a higher rate of return than other groups to investments in secular education, further reinforcing the productivity of investments in schooling. ${ }^{16}$ Few American Jews, however, were prepared to carry their religious studies to this point, and a perfunctory Jewish education can have little complementarity with American secular skills.

Gifted Jewish leaders recognized this problem early in the $20^{\text {th }}$ century and began working on ways to “Americanize” Jewish education. This process had two fronts. On the one hand, taking account of the secular human capital that Jewish students already had permitted Jewish educational methods to become more efficient. On the other hand, changes in American Jewish religious practice meant that the skills required for Jewish observance might differ from those needed in the old country. All three of the major synagogue movements developed new curricula and structures of Jewish education, organizing their schools with graded classrooms and developing English-language texts to complement the study of Hebrew. ${ }^{17}$

Although at first only a minority of the Jewish children acquired this education, by mid-century it was becoming the norm. Most of it took place in after-school programs 


\section{Chiswick - Shaping American Judaism}

affiliated with individual synagogues which were in turn affiliated with one of the larger synagogue movements. Typically meeting three days per week, twice on a weekday afternoon and again on Sunday mornings, these after-school programs provided the only Jewish education received by most of the children in Reform and Conservative congregations. Jewish day schools - that is, full-time parochial schools that provided both religious and secular education - were associated mostly with the Orthodox movement. Day schools were most common in cities with a substantial Jewish enclave neighborhood. As the immigrants assimilated and moved to the suburbs, Jewish day schools declined in number and enrolment until well after World War II. The Jewish day school “movement” has expanded dramatically in recent decades, in part because higher incomes have led to an expansion of private schools in general and in part because of an increased concern with Jewish education in particular. Although the proportion of children attending a Jewish day school is far higher among the Orthodox than the other movements, non-Orthodox and community-based Jewish day schools are a relatively new phenomenon with potentially important implications for the future of American Judaism.

\section{AMERICAN ECONOMICS AND WORLD JEWRY}

In 1880 nearly 90 percent of the world's Jewish population was concentrated in the Tsarist Russian Empire, with other communities in the Austro-Hungarian and Ottoman Empires and only 2 percent in the United States. Between 1880 until World War I, however, a mass migration from Russia and Eastern Europe to the United States significantly altered this distribution. By the early 1930s, on the eve of World War II, nearly 30 percent of the world's Jews lived in the US, another 60 percent in Europe 


\section{Chiswick - Shaping American Judaism}

(including Russia), and the remainder scattered in smaller communities in the rest of the world, including the British Mandate in Palestine. Then the Holocaust effectively destroyed European Jewry, and with the establishment of the State of Israel began a period of mass immigration of refugees from Europe and from Arab lands. As a result, the United States and Israel emerged as the two dominant Jewish communities during the second half of the twentieth century, each of which now accounts for approximately 40 percent of world Jewry. ${ }^{18}$

\section{AMERICAN AND EUROPEAN JEWRY}

As the Jewish community grew and the immigrants established an economic niche for themselves, Americans found themselves innovating new forms of Jewish observance compatible with an economic environment unlike those of the places where most other Jews were living. Throughout the first half of the $20^{\text {th }}$ century, American Jewish practices, customs and sensibilities increasingly diverged from those of the rest of the world. No matter how inward-looking Americans might be, however, they remained connected emotionally and traditionally to other Jews and especially to the Ashkenazi Jews of Europe. American Jewish charities included the needs of poor communities elsewhere, and American Jews were intensely concerned with political developments that affected the welfare of Jews in other countries.

International trade is especially profitable when factor prices differ across countries. In the United States, the prices of material goods were generally quite low and the opportunity cost of time was very high, in contrast to most of the rest of the world where the opposite was true. By the turn of the $20^{\text {th }}$ century American Jewry had developed an implicit system of international trade, exporting goods-intensive 


\section{Chiswick - Shaping American Judaism}

commodities (usually in the form of money) to other Jewish communities in exchange for time-intensive services (usually in the form of human capital). For example, American Jews provided financial support for yeshivas in Europe and hired their graduates, thus maintaining traditional Jewish institutions while avoiding the high opportunity cost of establishing similar schools in the United States. American Jews also participated in the development of the Jewish community in Israel by contributing money that supported the labor provided by Jewish immigrants to Israel from other countries.

Much as youthful challenge requires a stable authority against which to rebel, American Judaism could be bold in its pursuit of innovation because traditional religious institutions remained relatively strong in Europe. ${ }^{19}$ For the same reason, Israeli Jews were also able to concentrate on secular needs and felt free to make their own innovations in Jewish life. This security, reinforced by the possibility of international trade in religious skills, ended with the destruction of European Jewry in the Holocaust. Apart from its emotional and theological impacts, the Holocaust dramatically altered the economic exchange patterns of World Jewry. No longer would Europe be a source of religious human capital and the guarantor of continuity for ancient traditions. If the ancient treasures of Jewish religious culture were to survive at all, they would have to be preserved by the "new" Jewish communities in the United States and Israel.

What followed was a realignment of priorities, in which each of the three main synagogue movements sought to position themselves as preservers of Jewish tradition in an American setting. The Reform movement became less radically rebellious against religious traditionalism, moving away from its German roots to a less formal, more individualistic synagogue culture accessible to Americans with little Jewish religious 


\section{Chiswick - Shaping American Judaism}

education. The Conservative movement increased its emphasis on Zionism, not only as a means of supporting World Jewry but also for Israel's potential to enrich the religious life of American Jews. Orthodox Judaism’s declining membership was checked and eventually reversed, in part because of a renewed appreciation of the value of traditional religion and in part because of the stimulus it received when an important remnant of European yeshiva life immigrated to the United States. Unlike the case in previous generations when economic considerations were paramount, today’s American Jews with their relatively high incomes and secure identities tend to affiliate with the movement that best expresses their own religious temperament.

\section{AMERICAN JEWRY AND ISRAEL}

With the establishment of Israel as an important Jewish community, American Jewry found new opportunities for religious exchange. At first this was primarily a matter of money, with American Jewish donations to the new State supporting its economic development and refugee settlement. American financial contributions were also important for supporting the educational, medical and social infrastructure that helped Israel develop rapidly into a strong modern economy. By the 1960s, however, American Jews were beginning to visit Israel in person where their Judaism was influenced in other ways. When it came to Jewish human capital, Israeli Jews had a comparative advantage relative to American Jews for skills related to the Hebrew language and to biblical history and geography, whereas the Jewish education of Americans focused mainly on synagogue and holiday traditions developed in the Diaspora. By the last decades of the $20^{\text {th }}$ century modern Hebrew had become an important part of the American Jewish curriculum, sometimes with a semester or two in 


\section{Chiswick - Shaping American Judaism}

Israel but more often with an Israeli-trained teacher in America. American synagogues and Hebrew Schools would be influenced by the music, art and politics of Israeli Jewry, and vice versa.

With the development of Israel into a high-technology modern economy, the economic environment of Israeli Jews has partially converged to that of the United States, and this has induced a corresponding partial convergence of their Jewish practices. ${ }^{20}$ There still remain important differences. American Jewry is a tiny minority in a large country, while Israeli Jewry is a large majority in a tiny country. The United States is also characterized by religious pluralism with no government support for any specific religious group, whereas Israel is a Jewish state whose government supports several recognized religions. The possibility of capturing state financial support provides an economic incentive for religious groups to organize into political parties, a phenomenon common in Israel but virtually unheard of in the United States.

The entry of religion into the electoral system has other economic implications. Religious affiliation affects political outcomes, and political motives affect religious rhetoric. Israel's electoral system tends to generate many political parties and to favor groups in the extremes of the political spectrum, including the extremes of the religious spectrum. In contrast, American pluralism tends to favor the center in both political and religious spheres. In consequence, the proportion of Jews at either extreme of the religious spectrum, whether ultra-Orthodox or ultra-secular, is very much smaller in the United States than it is in Israel. Interactions between the two communities may erode this distinction, especially among the ultra-Orthodox where the financial and religious ties are much closer than elsewhere. Despite their growth in recent years, however, the 


\section{Chiswick - Shaping American Judaism}

ultra-Orthodox remain a small fraction of American Jewry and are unlikely to reach the importance of their Israeli counterparts. As long as the United States continues its separation of church and state, the large majority of American Jewry is likely to continue to locate itself at the center of the Jewish religious spectrum.

\section{ECONOMICS AND ASSIMILATION IN AMERICA}

Economic and social assimilation into the American mainstream was an important objective for Jewish immigrants and their children. They pursued it with dedication and intelligence, and they achieved it in a remarkably short time. In Europe, being a Jew was like having an ascribed trait that was difficult, if not impossible, to shed even for those who converted to another religion, married and raised their children in another faith. Many of the Jewish immigrants to the United States viewed their Judaism as an unwanted old-country artifact that they were prepared to leave behind, and in America they found this to be possible. For most, however, America was a land of economic opportunity regardless of the fact that they were Jews. Even as they strove for economic and social assimilation, few of them expected that American religious pluralism would be in any way a threat to Jewish continuity.

By the end of the twentieth century assimilation was defined differently, as a loss of meaningful Jewish identity, and is now perceived by many to threaten the very survival of American Judaism. As discussed earlier, immigrants invested heavily in their children’s secular education without making corresponding investments in Jewish education. When these children grew up and had children of their own, they had little to offer in the way of parental Jewish knowledge. Following values established in the 


\section{Chiswick - Shaping American Judaism}

immigrant communities of their youth, many of them viewed Jewish religious ritual as a set of quaint old-country traditions without importance in America. Although rising levels of education, occupations and earnings soon placed them comfortably in uppermiddle-class suburbs, the price of that rapid success was the loss of specifically Jewish human capital.

The immigrants themselves, now grandparents, might provide the family with whatever Jewish tradition they could, but it will be recalled that the immigrants themselves tended to be self-selected for below-average attachment to religious traditionalism. Moreover, children are more likely to turn to their parents as role models rather than their grandparents. Thus the absence of Jewish education in one generation would be passed on to the next, and each successive generation would have less and less Jewish human capital. Coupled with ever-higher levels of secular human capital, this would induce a reallocation of time away from Jewish observance in favor of secular pursuits, whether work or leisure. Young Jews in later generations would either ignore their Judaism entirely, placing little value on it, or they would feel the need to acquire more Jewish education than their parents, often citing a grandparent as inspiration. By the end of the $20^{\text {th }}$ century American Jews would effectively split into two groups, those whose Judaism was effectively lost - the fully assimilated Jews - and those whose Judaism was increasing in intensity and thus giving rise to a Jewish "renaissance.” ${ }^{21}$

The most visible symptom of religious assimilation is Jewish intermarriage, by which is meant the situation where a Jew marries a non-Jewish spouse. In most of these marriages children are raised either as non-Jews or as Jews in little more than name only. Unlike the situation in most of Jewish history, many non-Jews in American have 


\section{Chiswick - Shaping American Judaism}

educational, economic and social backgrounds quite similar to those of Jews. Further, many of these non-Jews lack the intense anti-Semitic attitudes characteristic of European society and are only loosely attached to their own religions. Most American Jews have many opportunities to meet non-Jewish friends, classmates and colleagues, readily finding possibilities for a suitable match on characteristics other than religion. The main incentive to select a partner that is Jewish is to improve the efficiency of making a Jewish home, an important component of Jewish religious observance. Even if both of his or her parents were themselves Jewish, a young person raised in a home with little or no Jewish observance or content is unlikely to view this as a high priority. Religious intermarriage at the end of the $20^{\text {th }}$ century may thus be seen as an unintended consequence of educational and lifestyle choices made earlier in the century.

The number of American Jews effectively "lost” to the community through religious assimilation and intermarriage is substantial, but an important minority remains committed to Judaism and if anything is strengthening Jewish religious culture in the United States. Not every immigrant neglected their children's Jewish education, and even some that did have observed their offspring choosing to "return" to Judaism. Most synagogues and their schools have adapted more or less successfully to the American environment. Developments in Israel fed into American Jewish life in creative ways, and the high comfort level of Jews in American society led to more visibility in Jewish observances. Many colleges and universities have courses and even whole programs in Jewish Studies. The three main synagogue movements of the last century are now joined by a variety of additional (or alternative) movements, including those that style themselves as "post-denominational" and a variety of groups that are characterized in the 


\section{Chiswick - Shaping American Judaism}

aggregate as "ultra-Orthodox." This pluralism within the Jewish community is an important part of American Judaism's response to the community's economic success.

\section{AN ECONOMIC FORCAST OF THE FUTURE}

The economic environment of American Jewry during the $20^{\text {th }}$ century was one of rapid transition. At the beginning most Jews were immigrant blue-collar workers, with little secular schooling and poor English skills. By mid-century they had climbed out of poverty, raised their education levels and moved into occupations at the forefront of American technological progress. At the end of the century most young adult Jews were third- or fourth-generation Americans, well-educated, raised in upper-middle-class suburban comfort and fully integrated into American society.

American Jewish institutions were influenced not only by differences between the economic environment of the United States and that of other countries, but also by the rapidly changing economic circumstances of American Jews. To a large extent, Jewish institutions were formed by, and catered to, the needs of an upwardly mobile community, within which there was much inequality as some advanced more rapidly than others. Now that the Jewish community is fairly stable at a high level of economic achievement, and is more homogeneous with respect to income and occupations, the older institutions no longer speak to its current needs. The American Jewish community now finds itself adapting its synagogues and communal institutions to yet another new economic environment and to the new Jewish needs of its members.

In contrast to the upward mobility of the past, the economic environment of today's Jewish community appears to exhibit a large degree of intergenerational stability. 


\section{Chiswick - Shaping American Judaism}

Highly educated parents place a high value on the education of their own children and provide them with a family background that advantages them in school. Highly educated parents also work in well-paying professional and managerial occupations that inevitably advantage their children for similar work. People in well-paid occupations also have a high opportunity cost of time, an incentive to substitute in consumption away from timeintensive activities. In particular, they have an incentive to have fewer children and invest heavily in the human capital of each child. Smaller, well-off families tend to invest similarly in both daughters and sons, and young adults tend to marry people with similar age, education, and even occupational characteristics. Most of today’s Jewish families are two-career professional couples who expect their own children to grow up into a community with similar economic characteristics.

For the most part, different types of human capital are mutually complementary, in that investment in one type raises the rate of return to investments in others. This means that high levels of secular education increase not only work-related skills but also the incentives to invest in health, in leisure-related activities, in family-related human capital, and in religious skills. American Jews are making all of these investments, and they can be expected to continue doing so. Even though the current Jewish renaissance is important for only a minority of today’s young adult Jews, it is probably a transitional phase, bridging the gap between low levels of Jewish human capital in the past and relatively high levels in the somewhat smaller but more intensely committed American Jewish community of the future. How high these future levels will be, and how many Jews continue to identify strongly with Judaism, depends in large part on how 


\section{Chiswick - Shaping American Judaism}

successfully Judaism and Jewish communal institutions can respond to the $21^{\text {st }}$-century

American economic environment.

\section{REFERENCES}

Chiswick, Barry R. “The Occupational Attainment and Earnings of American Jewry, 1890-1990”, Contemporary Jewry, 20 (1999), 68-98.

Chiswick,Carmel U. Economics of American Judaism (London: Routledge, 2008).

Lehrer, Evelyn L. Religion, Economics, and Demography: The Effects of Religion on Education, Work, and the Family (London: Routledge, 2009).

Warner, R. Stephen "Work in Progress toward a New Paradigm for the Sociological Study of Religion in the United States”, American Journal of Sociology, 98/5 (1993), 1044-93.

\section{ENDNOTES}

${ }^{1}$ For data on the occupations of American Jews see the chapter by Barry R. Chiswick in this volume.

${ }^{2}$ For the economics of immigrant adjustment see Barry R. Chiswick, "The Effect of Americanization on the Earnings of Foreign-Born Men”, Journal of Political Economy, 86/5 (1978), 897-921. Reprinted in Barry R. Chiswick, The Economics of Immigration: Selected Papers of Barry R. Chiswick (Northampton, MA: Edward Elgar, 2005).

3 For a fuller development of the role of immigrant churches in the United States See R. Stephen Warner and Judith G. Wittner (eds.), Gatherings in Diaspora: Religious Communities and the New Immigration (Philadelphia: Temple University Press, 1998).

4 Jonathan Sarna, "New Paradigms For the Study of American Jewish Life." Contemporary Jewry 24 (2004), pp. 157-169.

${ }^{5}$ Barry R. Chiswick, op.cit. (1978).

${ }^{6}$ For a fascinating description of this process see Jonathan D. Sarna, American Judaism: A History (New Haven: Yale University Press, 2004). 


\section{Chiswick - Shaping American Judaism}

${ }^{7}$ The graduation dinner was a gilded-age affair with many elaborate courses, each one of which violated the laws of kashrut. There are many descriptions of this event and its farreaching consequences. See, for example, Jonathan D. Sarna, American Judaism: A History (New Haven: Yale University Press, 2004).

${ }^{8}$ The term "immigrant church" is used broadly in the Sociology literature to include any house of worship serving a largely immigrant community, often using the language and customs of their country of origin. Warner and Wittner (eds.), op. cit. (1998) presents detailed descriptions of a number of immigrant churches at the end of the $20^{\text {th }}$ century.

${ }^{9}$ For an excellent exposition of this phenomenon and its related terminology see R. Stephen Warner, "Work in Progress toward a New Paradigm for the Sociological Study of Religion in the United States”, American Journal of Sociology, 98/5 (1993), 1044-93.

${ }^{10}$ For an interesting description of this and other aspects of Jewish immigrant culture see Jemma Weissman Joselit, The Wonders of America: Reinventing Jewish Culture 18801950 (New York: Hill and Wang, 1994).

${ }^{11}$ Carmel U. Chiswick, “Occupation and Gender: American Jews at the Millenium”. Paper presented to the Seminar on Creating and Maintaining Jewish Families (Brandeis University, 2007). The data are from the National Jewish Population Survey 2000/01.

12 Data on the occupations of Jewish men are from various sources as reported in Barry R. Chiswick, "The Occupational Attainment and Earnings of American Jewry, 1890 to 1990”, Contemporary Jewry 20 (1994), 68-98, and Barry R. Chiswick, “The Occupational Attainment of American Jewry: 1990 to 2000”, Contemporary Jewry, 27 (2007), 80-111.

${ }^{13}$ Carmel U. Chiswick, op. cit. (2007).

14 Jonathan D. Sarna, "New Paradigms for the Study of American Jewish Life", Contemporary Jewry, 24 (2004), 157-69.

${ }^{15}$ For further development of this point see Carmel U. Chiswick, "The Economics of Jewish Immigrants and Judaism in the United States.” Papers in Jewish Demography 1997 (2001), pp.331-344. Reprinted in Carmel U. Chiswick, Economics of American Judaism (London: Routledge, 2008)

${ }^{16}$ See, for example, Barry R. Chiswick, "Differences in Education and Earnings across Racial and Ethnic Groups: Tastes, Discrimination, and Investments in Child Quality”, Quarterly Journal of Economics, 103 (1988), 571-97.

${ }^{17}$ Sarna, American Judaism: A History (New Haven: Yale University Press, 2004) and Jack Wertheimer, “Jewish Education in the United States: Recent Trends and Issues”, in 
David Singer (ed.), American Jewish Year Book 1999 (New York: American Jewish Committee, 1999), 3-115.

18 These data are from Sergio DellaPergola, "World Jewish Population 2006”, American Jewish Yearbook 2006 (New York: American Jewish Committee), and from unpublished tables compiled by Barry R. Chiswick

${ }^{19}$ In fact, the forces of modernity were challenging religious authority in Europe as well. Changes in European Judaism were undoubtedly slowed, however, by the opportunity for dissidents to emigrate. If immigrants to America had a large component of Jews selfselected to be less observant than the average, this would have reinforced their economic incentives to deemphasize Jewish religious education.

${ }^{20}$ For a fuller discussion of this proposition see Carmel U. Chiswick, "Israel and American Jewry in the Year 2020: An Economic Analysis”, in Anat Gonen and Smadar Fogel (eds.), The Macro Scenarios: Israel and the Jewish People (Israel 2020: Master Plan for Israel in the Twenty-First Century; Haifa: The Technion, 1996), 257-72 (Hebrew). The original English version is available in Carmel U. Chiswick, Economics of American Judaism (London: Routledge, 2008).

${ }^{21}$ The economic theory summarized in this paragraph is developed in C. U. Chiswick, op cit. 1997. For a discussion of the Jewish "renaissance” see Jack Wertheimer, A People Divided: Judaism in Contemporary America. (New York: Basic Books, 1993). 